\title{
Tako-Tsubo Cardiomyopathy: A Recent Clinical Syndrome Mimicking an Acute Coronary Syndrome
}

\author{
Montassier Emmanuel1, Segard Julien ${ }^{1}$, Arnaud Martinage ${ }^{1}$, \\ Nicolas Piriou ${ }^{2}$, Philippe Le Conte ${ }^{1}$, Gilles Potel $^{1}$ and Jean Pierre Gueffet ${ }^{2}$ \\ ${ }^{1}$ Emergency Department, Hotel Dieu Teaching Hospital \\ ${ }^{2}$ Cardiology, Laennec Teaching Hospital, Nantes
}

France

\section{Introduction}

Tako-Tsubo cardiomyopathy (TTC), first described in 1990 by Sato in Japan (Sato et al., 1990), has recently gained increasing consideration when reported in non-Japanese patients, including the United States and Europe (Hachamovitch et al., 1995; Sharkey et al., 2005; Desmet et al., 2003; Bybee et al., 2004; Dec, 2005; Kurowski et al., 2007)

Typical presentation mimics acute coronary syndrome, with acute chest pain and/or dyspnoea, associated to electrocardiographic changes and moderate cardiac biomarkers release, but in which coronary angiography reveals no coronary arteries lesions. Echocardiography and left ventriculography show the characteristic abnormalities: a reversible left ventricle systolic dysfunction (Pilgrim et al., 2008; Prasad et al., 2008; Wittstein et al., 2005). These transient regional wall motion abnormalities, involving typically the left ventricle, usually extend beyond a single vessel territory (Sato et al., 1990; Dote et al., 1991).

An expert consensus panel proposes a definition of TTC: "TTC is a recently described clinical entity characterised by acute but rapidly reversible left ventricle systolic dysfunction in the absence of atherosclerotic coronary artery disease, triggered by profound psychological stress. This distinctive form of ventricular stunning typically affects elderly women and preferentially involves the distal portion of the left ventricle chamber (apical ballooning), with the basal left ventricle hypercontractile. Although presentation often mimics ST-segment Elevation Myocardial Infarction, outcome is favourable with appropriate medical therapy" (Maron et al., 2006).

The classical, first described, variant of TTC manifests as ballooning of the apical segment and compensatory hypercontraction of the middle-to-basal segments of the left ventricle during systole, similar to the Japanese octopus-trap pot, called Tako-Tsubo (Sato et al., 1990; Dote et al., 1991). Several variants of TTC have been reported recently, involving any part of the heart, but most commonly the left ventricle (Hahn et al., 2007; Kurowski et al., 2007; Pilliere et al., 2006; Reuss et al., 2007; Hurst et al., 2006).

The incidence of TTC, also known as stress-induced cardiomyopathy, transient apical ballooning or broken heart syndrome, is estimated to be present in $1.7 \%$ to $2.2 \%$ of the patients with suspected acute coronary syndrome (Wittstein et al., 2005; Akashi et al., 2010; 
Pavin et al., 1997; Brandspiegel et al., 1998; Flavahan 2006). TTC typically occurs in postmenopausal women, with a mean age ranged between 58 to 75 . The condition is frequently precipitated by emotional or physical stress but a triggering event may not be identified (Bybee et al., 2004; Gianni et al., 2006).

Prognosis is good, in contrast to acute coronary syndrome, provided that the patients survive the possible life-threatening acute presentation, with correction of the left ventricle dysfunction within several days or weeks (Bybee et al., 2004; Gianni et al., 2006; Nef et al., 1993; Prasad et al., 2008; Krishnan et al., 2009; Pernicova et al., 2010).

\section{Search strategy}

The review was based on a thorough search of evidence-based sources of information, including the Cochrane Database of systematic Reviews and the electronic database Medline with the MeSH terms "Tako-Tsubo cardiomyopathy", "Tako-Tsubo syndrome", "stress cardiomyopathy", "apical ballooning syndrome", "catecholamines". Papers cited include English and French-language articles.

Table 1. Search strategy and review criteria.

\section{Clinical Features}

\subsection{Clinical presentation}

The clinical presentation of TTC is similar to an acute coronary syndrome, usually indistinguishable from an acute coronary syndrome and resembling an ST Elevation Myocardial Infarction. Acute phase includes substernal chest pain and/or dyspnoea (Bybee et al., 2004; Gianni et al., 2006). 70 to $90 \%$ of the patients exhibit chest pain at rest, referring it as the most common symptom. Mild to moderate congestive heart failure is common. Non specific symptoms including syncope, weakness and nausea have also been reported (Hurst et al., 2010). Moreover, few patients were described as asymptomatic, often admitted for non cardiac illnesses, and TTC was suspected on electrocardiogram or cardiac biomarkers.

Life-threatening initial symptoms are uncommon and out-hospital cardiac arrest due to cardiac rupture has also been very rarely recorded (Akashi et al., 2004; Ohara et al., 2005). However, hemodynamic compromise may occur, related to acute complications such as ventricular tachycardia, ventricular fibrillation, severe congestive heart failure or left ventricular outflow tract obstruction (Valbusa et al., 2008; Prasad et al., 2008).

\subsection{Population}

The cardiomyopathy usually affects women over 50 years of age, with a mean age ranged between 58 to 75 years, with approximately $3 \%$ of the cases in patients under 50 years of age (Prasad et al., 2008). TTC was rarely described in the male population, representing less than $10 \%$ of all the cases (Bybee et al., 2004; Tsuchihashi et al., 2001; Sharkey et al., 2005; Akashi et al., 2008; Kurowski et al., 2007). In this population, cardiac risk factors seem to be less described, whereas highest prevalence of anxiety or depression was reported (Kurowski et al., 2007; Vidi et al., 2009; Mudd et al. 2007; Pace et al., 2011). 


\subsection{Incidence}

TTC is an infrequent cardiomyopathy, representing 0,7 to $2,2 \%$ of the patients with suspected acute coronary syndrome admitted to the hospital (Wittstein et al., 2005; Akashi et al., 2010; Pavin et al., 1997; Brandspiegel et al., 1998; Flavahan, 2006; Bybee et al., 2004; Gianni et al., 2006). A similar prevalence was reported from a registry of patients with troponine-positive acute coronary syndrome (Kurowski et al., 2007). The annual incidence of TTC was estimated to be 0,00006 to $0,05 \%$ (Klinčeva et al., 2007; Pilliere et al., 2006). Recently, Italian multicenter studies have showed a variation in TTC occurrence with a summer and morning peak. Moreover, they have also described a weekly variation with a significant Monday peak in the working population (Manfredini et al., 2010; Gallerani et al., 1992). However, other series found differing results in terms of peak of occurrence (Mansencal et al., 2010).

\section{Precipitating events}

\subsection{Preceding stressful event}

A main feature of the TTC is that it usually follows an identifiable emotional or a physical stressful event. This condition is found in approximately two thirds of the TTC patients (Sharkey et al., 2010; Elesber et al., 2007; Gianni et al., 2006).

In the case of seasonal, weekly, circadian variations of TTC occurrence, stress caused by resuming working activities after a break was suggested as a triggering factor (Manfredini et al., 2010). A recent study has showed that in TTC patients, a high-anxiety trait is common but not significantly higher as compared with ST Elevation Myocardial Infarction patients. Moreover high-anxiety trait is not a predictor of TTC in patients with suspected acute coronary syndrome (Pace et al., 2011).

\subsection{Emotional stressful event}

Numerous emotional factors have been noted: being informed of the death of a loved one, receiving tragic news, public speaking, heated argument, marital discord, spousal departure, accidents and financial loss, unexpected bill, surprise birthday party, babysitting grandchildren, assault, loved one hospitalisation, car accident, catastrophic medical diagnosis, jellyfish sting, natural disaster: earthquarke, Xynthia tempest (Bielecka-Dabrowa et al., 2010; Wittstein et al., 2005 ; Watanabe et al., 2005; Hurst et al., 2010; Bybee et al., 2004; Parodi et al., 2007; Prasad et al., 2008; Sharkey et al., 2005; Trebouet et al., 2011; Movaheda et al., 2007, Montassier et al., 2009).

\subsection{Physical stressful event}

\subsubsection{General anesthesia}

Numerous cases of TTC related to general anesthesia have been described, involving various surgical procedures such as digestive surgery (cholecystectomy, hepatectomy, colectomy, hernia repair), cardiothoracic surgery, orthopedic surgery, eye surgery. In such cases, several mechanisms may represent the triggering event: preoperative anxiety, stress of surgery, induction of anesthesia, laryngoscopy, perioperative hemodynamic instability, perioperative administration of vasopressors agents, extubation, and postoperative pain (Liu et al., 2010; Lentschener et al., 2006; Gavish et al., 2006; Takayama et al., 2004; Liu S et al., 2008; Ramakrishna et al., 2005; Takigawa et al., 2003; Mizutani et al., 2002; Itoh H et al., 2007; Littlejohn et al., 2008; Jabaudon et al., 2007). 


\subsubsection{Other physical stressful events}

Gastrointestinal triggers have been commonly reported (high-intensity vomiting, diverticulitis, pelvic abscess, acute cholecystitis, pancreatitis, pseudomembranous colitis) but other physical stressful event have been showed to act as triggering events, such as cardiac stress test, severe pain, asthma or chronic obstructive airway exacerbation, sepsis, acute intracranial events (intracranial bleeding, head trauma, ischemic stroke, epileptic seizure), thyrotoxicosis (Dorfmann al., 2007; Rossor et al., 2007; Ionescu et al., 2010; Sharkey et al., 2005; Bybee et al., 2004; Gianni et al., 2005; Rajani et al., 2010).

Several cases have been reported after administration of pharmacologic agents: beta-agonist bronchodilator, epinephrine, norepinephrine, dobutamine. All these are exogenous cathecolaminergic agents (Abraham et al., 2009; Cherian et al., 2008; Winogradow et al. 2011). Several cases have been noted to be connected to cocaine use, opiate withdrawal or excessive alcohol consumption (Daka et al., 2007; Rivera et al., 2006).

TTC has also been described following a normal vaginal delivery or after caesarean delivery (Teh et al., 2010; Zdanowicz et al., 2011; Citro et al., 2010; Crimi, 2008; Muller et al., 2007; Parodi et al., 2007; Hawthorne et al., 1997). These cases in premenopausal women highlight the potential role of estrogens in TTC etiopathogenesis and the interaction of the latter with catecholamines.

Recently, several cases have been reported in postmenopausal women underlying malignancies (Fazio et al., 2010; Abe et al., 2003; Kawai et al., 2000). In these conditions, precipitating factors could be the context of a stressor or paraneoplastic phenomenon, but the link remains unclear.

\section{Electrocardiogram and cardiac biomarkers}

\subsection{Electrocardiogram findings}

As clinical presentation, TTC is indistinguishable from an acute coronary syndrome based on ECG analysis and ECG findings may vary at presentation. Most frequently, the ECG characteristics of the TTC are consistent with ST-segment elevation, mimicking an ST-elevation myocardial infarction, typically in the anterior precordial leads (Bybee et al., 2007; Ogura et al., 2003; Kurisu et al., 2004; Tsuchihashi et al., 2001). Inferior or lateral leads could also be involved. ST-segment is reported in approximately 30 to $50 \%$ of the TCC patients (Sharkey et al. 2010; Abe et al., 2003; Akashi et al., 2005; Kurisu et al., 2002; Elesber et al., 2007; Sato et al., 2006; Tsuchihashi et al., 2001; Dib et al., 2009). Moreover, transient ST-segment isolated elevation in lead aVR has also been described in the TTC patients (Rostoff et al., 2009).

The next most common ECG characteristic in TTC are deep T wave inversions, especially in precordial leads, and frequently associated with corrected QT interval prolongation. These ECG abnormalities have been reported in several series (Krishnan et al., 2009; Kim et al., 2010; Silva et al., 2009). Furthermore, these corrected QT interval prolongations have been noted to be correlated with highest occurrence of ventricular fibrillation and extent of wall motion abnormalities in acute coronary syndrome patients (Yunus et al., 1996; Stajer et al., 1993).

Transient pathological Q waves may rarely develop in TTC patients (Rostoff et al., 2009; Krishnan et al., 2009; Kim et al., 2010; Silva et al., 2009). Moreover, a new bundle-branch block or a normal ECG may be found at presentation (Prasad et al., 2008; Bybee et al,. 2007; Ogura et al., 2003; Kurisu et al., 2004; Tsuchihashi et al., 2001; Sharkey et al. 2010).

Atrial and ventricular arrhythmias may occur, but ventricular tachycardia and fibrillation are rarely reported, occurring in $1 \%$ to $6 \%$ of the patients (Matsuoka et al., 2003; Denney et 
al., 2005; Bonello et al., 2008). Moreover, despite the frequent corrected QT interval prolongation, the occurrence of torsades de pointes is rarely described (Elkhateeb et al., 2008; Dib et al., 2008).

\subsection{Cardiac biomarker}

The majority of the patients had a moderate cardiac troponin T release, with a peak within 24 hours (Sharkey et al., 2005; Bybee et al., 2004; Desmet et al., 2003). The discrepancy between the minor elevation in cardiac biomarkers and the extent of the wall motion abnormities is a hallmark of the TTC (Prasad et al., J 2008; Kurisu et al., 2004). Thus, this modest rise in cardiac biomarker may possibly help to distinguishes it from acute coronary syndrome.

Brain Natriuretic Peptide level is usually elevated. Furthermore, its rise, higher than that the one seen in acute coronary syndrome, is purely correlated with the left ventricle systolic dysfunction (Akashi et al., 2004).

\section{Coronary angiography and cardiac imaging}

As the clinical features of TTC are indistinguishable from the acute coronary syndrome, TTC, defined as a reversible left ventricle systolic dysfunction, may be diagnosed by coronary angiogram, echocardiography or cardiac magnetic resonance (Pilgrim et al., 2008; Prasad et al., 2008; Sharkey et al., 2005; Wittstein et al., 2005).

Classically, at presentation, transthoracic echocardiography and left ventriculography show the characteristic regional wall motion abnormalities involving hypokinesis or akinesis of apex and mid segments of the left ventricle with hyperkinesis in basal segment.

Thus, the classical abnormality is revealed as an apical ballooning of the apex with systole, in the shape resembling to a traditional Japanese jar used for catching octopus, which was named "Takotsubo". The name of the syndrome is derived from this fisherman's device (Sato et al., 1990; Dote et al., 1991; Pilgrim et al., 2008; Pilgrim et al., 2008; Prasad et al., 2008; Sharkey et al., 2005; Wittstein et al., 2005).

\subsection{Echocardiography}

Clearly, the widespread use of echocardiography, especially in critical care patients, is responsible for the recent increased frequency of TTC recognition (Sharkey et al., 2005; Park et al., 2005; Haghi et al., 2006). However, in the acute phase, echocardiography may not help to distinguish TTC from acute coronary syndrome in view of regional wall motion abnormalities. Thus, diagnosis is frequently made by cardiac catheterization (Bybee et al., 2004; Hurst et al., 2010).

\subsection{Coronary angiography}

It is worth noticing that the wall motion abnormalities involving more than one particular coronary artery territory are a hallmark of TTC (Prasad et al., 2008; Krishnan et al., 2009). This TTC characteristic is most frequently identified during left ventriculography. Moreover, in patients with TTC, coronary angiography shows normal coronary arteries or coronary arteries with no significant disease ( $<50 \%$ luminal stenosis) (Pilgrim et al., 2008; Prasad et al., 2008; Sharkey et al., 2005; Bybee et al., 2004; Gianni et al., 2006). Thus, when the coronary anatomy is free of significant atherosclerotic lesions with wall motion abnormalities of the left ventricle, usually of the apex, and unrelated to a single coronary 
artery territory, the diagnosis of TTC may be postulated. As the patients are supposed to suffer from an acute coronary syndrome, the diagnosis of TTC is currently made during left ventriculography, showing the typical regional wall motion abnormalities.

In the acute phase, severe left ventricle systolic dysfunction is frequently noted, with ejection fraction decreasing from $10 \%$ to $30 \%$. In a review of several series, the mean ejection fraction ranged from 20 to 49\% (Bybee et al., 2004; Gianni et al., 2006).

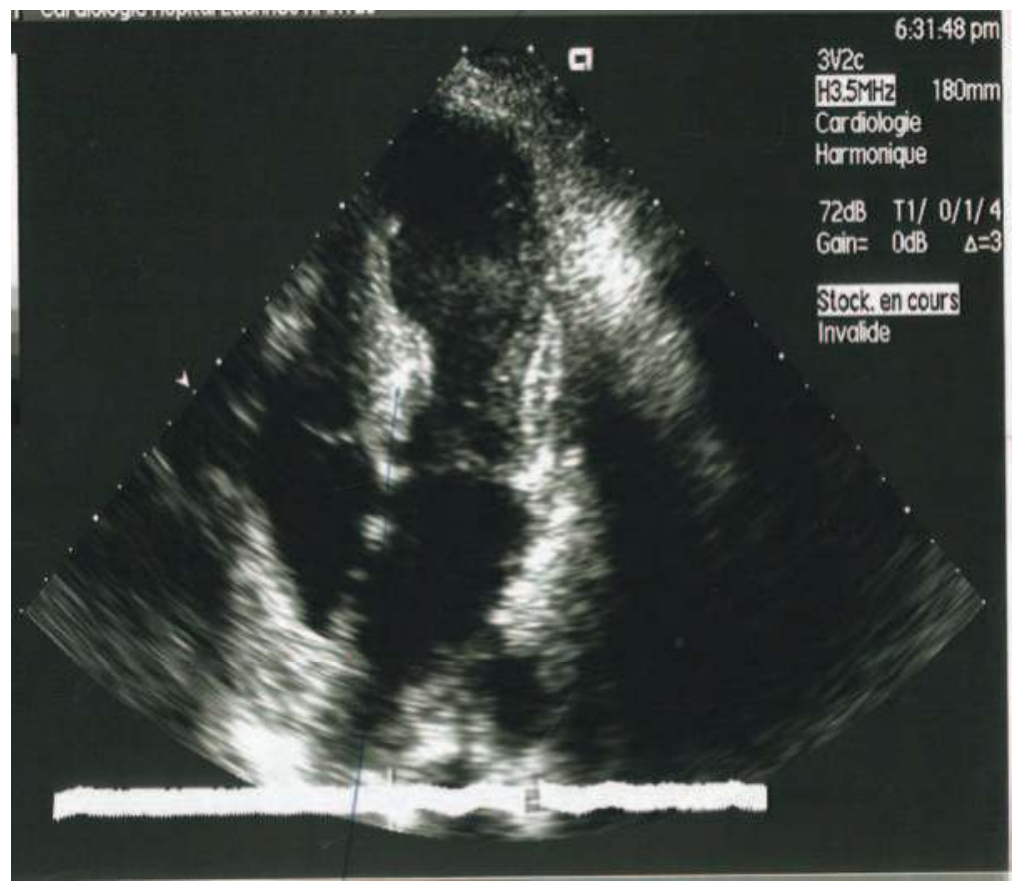

Fig. 1. Echocardiography showing hypokinesis of the apex with hyperkinesis of the base of the left ventricle.

Several variants of TTC have been described, related to a variety of angiographic presentations, involving different areas of the left ventricle. Indeed, based on anatomic location, four different types of TTC are described in literature. All these patients have initially the same clinical presentation. The classic type, previously reported, is described as apical ballooning, with depressed contractile function of the mid and apical segment of the left ventricle and with compensatory hyperkinesis of the basal segments. This type is the most encountered in literature (Bybee et al., 2004; Gianni et al., 2006; Prasad et al., 2008; Abe et al., 2003). The second type is the reverse type in which patients present hyperdynamic apex, with hypokinesis or akinesis of the basal left ventricle segments. Given its distinct basal involvement with apical and mid-ventricular sparing, this type of TTC was considered to be atypical or inverted (Van de Walle et al., 2006; Abdulla et al., 2006; Mansencal et al., 2010). In a recent study, its prevalence was estimated to be $24 \%$ of all left ventricle variants of TTC (Mansencal et al., 2010). The third type involves the mid left ventricle wall, with sparing of the basal and apical segments. It is also called "midventricular ballooning" 
(Ohtsubo et al., 2005; Hurst et al., 2006; Tamura et al., 2007; Yasu et al., 2006). The fourth type is characterised by a localized wall motion abnormality affecting a segment of the left ventricle wall, usually the anterior wall (Suzuki et al., 2004; Lamm et al., 2007; Mazzarotto et al., 2005; Strunk et al., 2006). These variants of TTC have similar prognoses.

Furthermore, involvement of the right ventricle is commonly associated to left ventricle systolic dysfunction in TTC, revealed in 30\% of the patients (Elesber et al., 2006; Haghi et al., 2006; Novak et al., 2007). In these patients, the presence of right ventricle dysfunction seems

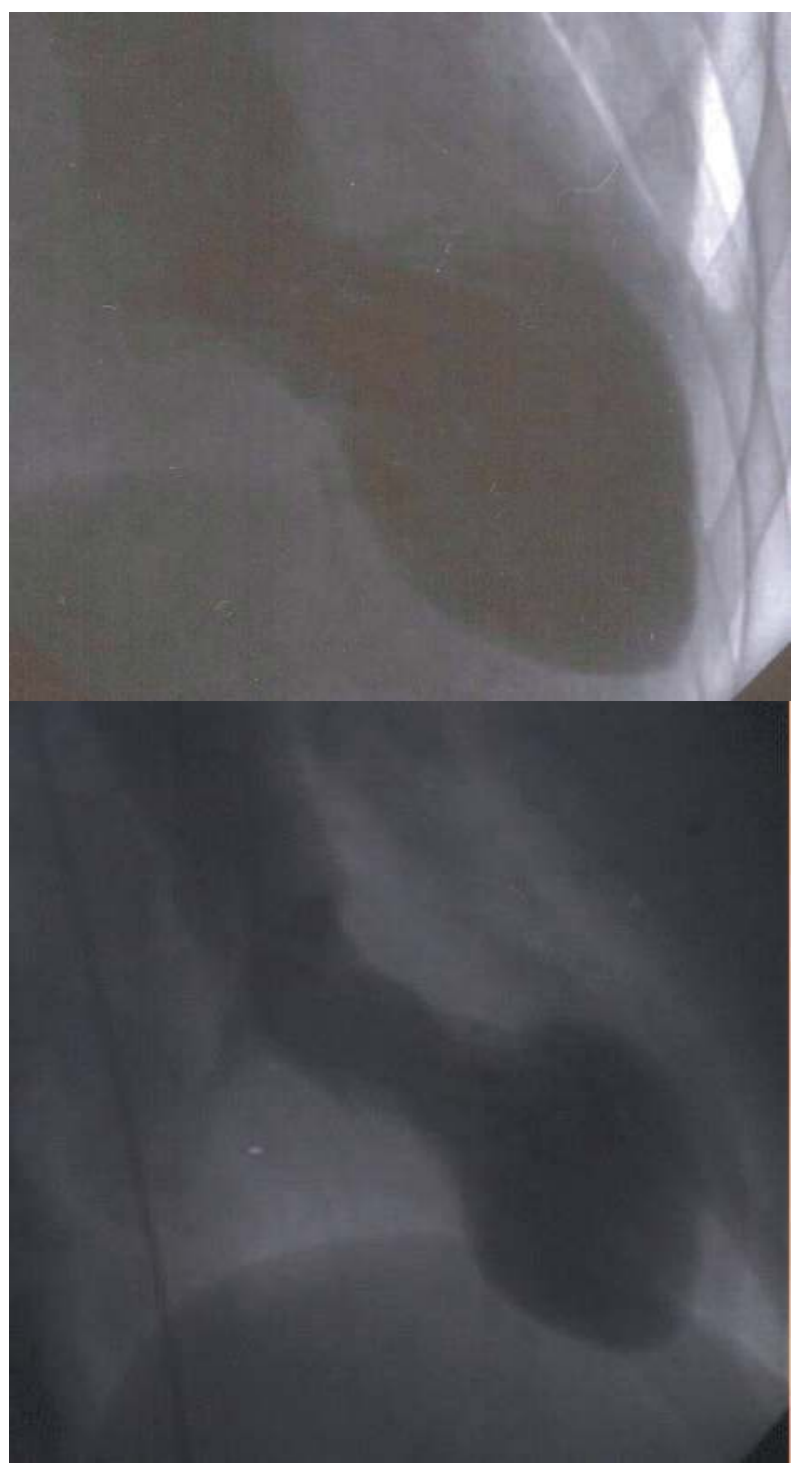

Fig. 2. Ventriculography in systole showing apical ballooning. 
to be associated with worse left ventricle systolic dysfunction, longer hospitalization and a higher possibility of development of severe complications, particularly occurrence of congestive heart failure (Prasad et al., 2008; Silva et al., 2009; Elesber et al., 2006; Haghi et al., 2006; Novak et al., 2007; Nef et al. 2010). A report described a case of TTC characterized by biventricular ballooning, pulmonary hypertension and hemodynamic compromise associated with prolonged hospitalisation, highlighting the fact that initial management should evaluate left ventricle function but also detect right ventricle involvement (Citro et al., 2010). In another series, association between right ventricle involvement and lower ejection fraction has not been shown (Teh et al., 2010). However, this condition should be immediately known as it possibly impacts outcome.

\subsection{Cardiac magnetic resonance}

Cardiac magnetic resonance is interesting in order to appreciate the extent of the regional wall motion abnormalities and the variety of depressed contractile function patterns. TTC is characterized by lack of delayed hyper-enhancement following gadolinium injection. Thus, this procedure may help differentiate TTC from acute coronary syndrome or myocarditis (Mitchell et al., 2007; Deetjen et al., 2006). Furthermore, cardiac magnetic resonance is the most accurate procedure in order to assess the right ventricle involvement in the cardiomyopathy (Haghi et al., 2007; Sharkey et al., 2010; Haghi et al., 2006). In addition, cardiac magnetic resonance may help identify ventricular thrombi not visualised by echocardiography (Sharkey et al., 2010). Thus, cardiac magnetic resonance is the best diagnosis procedure after the acute phase, when the patient's condition is stabilised.

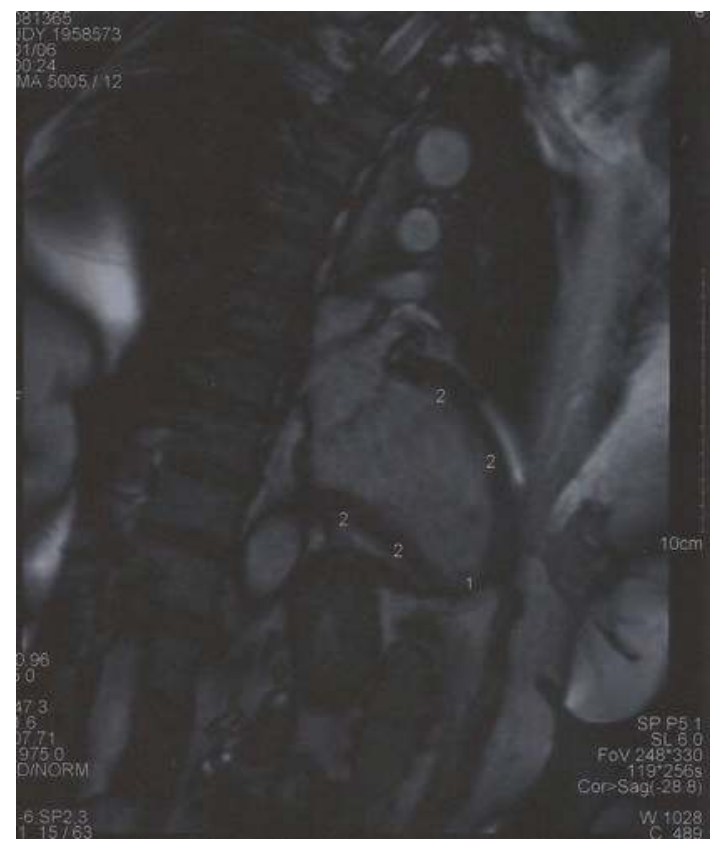

Fig. 3. Cardiac magnetic resonance image showing preserved contraction of the base of the ventricle and apical ballooning. 
Tako-Tsubo Cardiomyopathy:

A Recent Clinical Syndrome Mimicking an Acute Coronary Syndrome

\section{Diagnosis}

Two guidelines have been proposed for the diagnosis of TTC, based on a consensus of experts, because there is no diagnosis test of the condition. The first one was proposed by the Mayo Clinic in the United States and the other by the Tako-Tsubo Cardiomyopathy Study Group in Japan (Bybee et al., 2004; Prasad et al., 2007; Kawai et al., 2007).

The Mayo Clinic proposed criteria for the diagnosis of TTC included: (1) new electrocardiographic abnormalities (either ST-segment elevation or T wave inversion) or modest elevation in cardiac troponin, (2) transient hypokinesis, akinesis or dyskinesis of the LV mid segments with or without apical involvement, with wall motion abnormalities extending beyond a single epicardial vascular distribution, with a stressful triggering factor often, but not always, present, (3) absence of obstructive coronary disease or angiographic evidence of plaque rupture, (4) absence of pheochromocytoma or myocarditis.

The Mayo Clinic criteria were initially proposed by Bybee et al. and were secondly revised by Prasad et al (Bybee et al., 2004; Prasad et al., 2007). In the second modified version of the criteria for TTC, patients with intracranial bleeding were no longer excluded, including those with subarachnoid haemorrhage (Prasad et al., 2007).

For its part, the Japanese guideline calls the apical ballooning seen in cerebrovascular accidents and pheochromocytoma a Tako-Tsubo-like myocardial dysfunction (Kawai et al., 2007).

These guidelines include the different variants of TTC. Moreover, the most important feature of TTC is a documented correction of the ejection fraction. Thus, diagnosis of TTC may only be concluded after the recovery of the transient left ventricle systolic dysfunction, not only based on criteria at time of presentation.

1. New electrocardiographic abnormalities (either ST-segment elevation or T wave inversion) or modest elevation in cardiac troponin.

2. Transient hypokinesis, akinesis or dyskinesis of the LV mid segments with or without apical involvement, with wall motion abnormalities extending beyond a single epicardial vascular distribution, with a stressful trigger often, but not always, present,

3. Absence of obstructive coronary disease or angiographic evidence of plaque rupture

4. Absence of pheochromocytoma or myocarditis.

Table 2. Mayo Clinic proposed criteria for the diagnosis of Tako-Tsubo cardiomyopathy.

\section{Diagnosis strategy}

The differential diagnosis with an acute coronary syndrome is not yet possible in the acute phase based on clinical or laboratory features. Thus, the diagnosis should be considered in postmenopausal women, presenting with chest pain and/or dyspnoea, with no or few risk factors for coronary artery disease and history of recent stress associated to electrocardiographic abnormalities and a moderate cardiac troponin T release. Furthermore, the diagnosis should also be suspected in inpatients, especially in the intensive care unit population, with acute left ventricle systolic dysfunction associated to hemodynamic compromise, pulmonary oedema, electrocardiographic abnormalities consistent with an acute coronary syndrome or a cardiac troponin T release (Elesber et al., 2006; Haghi et al., 2006; Novak et al., 2007). 
The diagnosis of TTC is most frequently made during coronary angiography, performed as recommended by guidelines for the management of acute coronary syndrome. In fact, patients with TTC, due to their initial presentation similar to an acute coronary syndrome, are usually referred for urgent reperfusion therapy. The absence of fixed epicardial coronary artery disease and no angiographic evidence of plaque rupture or intracoronary thrombus formation associated with characteristic regional wall motion abnormality, as previously described, leads to the diagnosis. Thus, in patients with TTC, coronary angiography shows normal coronary arteries or coronary arteries with no significant disease $(<50 \%$ luminal stenosis). However, few patients exhibit a concomitant obstructive coronary artery disease in witch case cardiac magnetic resonance may be useful to distinguish TTC from acute coronary syndrome (Hoyt et al., 2009; Deetjen et al., 2006).

As briefly indicated above, in case of typical presentation of TTC, in a postmenopausal woman with chest pain related to a stressful event with no or few risk factors for coronary artery disease, coronary angiography should be considered as the first choice. Indeed, these patients may be exposed to inappropriate therapy such as thrombolysis, which may lead to serious complications, especially in this classical aged population (Kolkebeck et al., 2008). Thus, a good strategy seems to be to transfer a patient suspected of TTC to a cardiac catheterization laboratory for emergency coronary angiography and avoid the administration of fibrinolytic therapy. However, suspicion of the diagnosis of TTC is not sufficient to contraindicate fibrinolytic therapy if needed, as the great majority of patients with a ST-segment Myocardial Infarction will have an obstructive coronary disease. Basically, guidelines recommended managing these patients as usual, with urgent cardiac catheterization or with fibrinolytic therapy (Prasad et al., 2008; Reeder et al., 2010).

The diagnosis of TTC without cardiac catheterization is difficult and coronary angiography should be rapidly performed. Indeed, echocardiography realised in the acute phase may not help to distinguish the regional wall motion abnormalities of TTC from acute coronary syndrome, even if in case of TTC, the wall motion abnormalities involve more than one particular coronary artery territory. Moreover, the variants of the classical TTC pattern are harder to diagnose by echocardiography alone. However, sometimes, patients are contraindicated to undergo invasive strategy. In these patients, repeated echocardiography allows for the documentation of the correction of the left ventricle systolic dysfunction (Anand et al., 2010).

\section{Complications}

In the acute phase, complications may occur and life-threatening presentation is not rare. Indeed, acute complications have been shown in approximately $20 \%$ of the patients (Bybee et al., 2004; Bonello et al., 2008). Most of them are related to left ventricular heart failure, reported as follows (prevalence): pulmonary oedema (15\%), cardiogenic shock $(6,5 \%)$, left ventricle outflow tract obstruction $(11 \%)$, mitral regurgitation $(25 \%)$, ventricular mural thrombus formation (7\%) (Pernicova et al., 2010; Donohue et al., 2005; Akashi et al., 2004; Nef et al., 2006; Nef al., 2009; Bonello al., 2008; Barrera-Ramirez et al., 2003; Zaroff et al., 2000). In case of left ventricular thrombus formation, thromboembolic complications, such as stroke, occur in $0,8 \%$ of the patients (de Gregorio et al., 2008).

Arrhythmias are also described, including atrial or ventricular arrhythmias. Incidence of atrial fibrillation has been quoted at 15\%, ventricular tachycardia at 1,6\% (Bielecka-Dabrowa et al., 2010; Ionescu et al., 2010). QT prolongation resulting in torsades de pointes is a 
potential mechanism for ventricular arrhythmias (Bonello et al., 2008). This condition is involved in a large proportion of the syndrome mortality rate, as sudden cardiac death due to ventricular fibrillation was estimated to be $4 \%$ (Ionescu et al., 2010).

Other rare complications have been noted such as pneumothorax or left ventricular rupture (Bielecka-Dabrowa et al., 2010; Matsuoka et al., 2000; Sakai et al., 2005; Ohara et al., 2005). A TTC complicated by a ventricular septal dissection with a concomitant septal performation have been recently reported (Mariscalco et al., 2010). This patient never recovered a normal left ventricular systolic function. Furthermore, increase risk of bleeding has been noted secondary to anticoagulation prescribed in case of left ventricular thrombus formation or in case of inappropriate thrombolysis.

\section{Prognosis and recurrence}

\subsection{Prognosis}

Prognosis is favourable, provided that the patients survive the possible life-threatening acute phase, with full recovery of the left ventricular systolic function within several weeks, typically within 1 to 4 weeks (Bybee et al., 2004; Gianni et al., 2006; Nef et al., 2007; Prasad et al., 2008; Pernicova et al., 2010). Therefore, the correction of the left ventricle systolic dysfunction and the correction of the regional wall motion abnormalities during the electrocardiographic follow-up is a hallmark of the cardiomyopathy. However, a recent study has showed a more important delay in the correction of the left ventricular systolic dysfunction, with a normalisation in 2.5 to 12 months in $5 \%$ of their included patients (Sharkey et al., 2010).

As mentioned before, severe acute presentation may occur and in-hospital mortality rate is estimated to be $1.1 \%$ to $2 \%$, mostly related to arrhythmias or mechanical complications (Mariscalco et al., 2010). Thus, this data highlight the fact that TTC is not entirely benign and that TTC may require early and aggressive management. In several reviews, longterm survival seems to be similar to the one expected in the general population (Elesber, et al., 2006; Gianni et al., 2006). Late sudden death is particularly uncommon (Fineschi et al., 2010). However, a recent study has showed that survival, in two-third of the patients with TTC, was worst than in the general age- and sex-matched population. In their patients, mortality has always been related to noncardiac diseases, and for the authors, TTC may be a marker for impaired health (Sharkey et al., 2010). Another study found that the long-term mortality rate was higher than the long-term mortality rate in the general population and mostly due to patients' comorbidities. Moreover, in this study, the severity of the initial presentation was not correlated to long-term outcome (Parodi et al., 2010). Thus, long-term outcome remains unclear in patients with TTC and larger studies are needed to confirm these recent findings.

\subsection{Recurrence}

As noted in several reviews, $3.5 \%$ to $10 \%$ of the patients have a recurrence during the first few years after the initial presentation (Bybee et al., 2004; Gianni et al., 2006; Nef et al., 2007; Prasad et al., 2008). A recent 4-year follow-up study described $11.4 \%$ recurrence of TTC (Elesber et al., 2007). Published data has also showed that the different variants of TTC may differ on recurrence (Blessing et al. 2007). This recurrence occurs in particularly similar circumstances, highlighting the importance to educate the patients in order to banish stress or physical triggering factors (Sharkey et al., 2010). Furthermore, chest pain and dyspnoea 
recurrence occurs frequently. Indeed, a study indicated a rate of rehospitalisation for cardiac complaints estimated at $30 \%$ (Ionescu et al., 2010).

\section{Treatment}

\subsection{Acute phase}

In the acute phase, the treatment of TTC is empirical and mainly supportive, adapted on clinical presentation (Prasad et al., 2008). The objective is to correct the left ventricle systolic dysfunction with standard medication for left ventricle systolic dysfunction. Moreover, as the differential diagnosis with an acute coronary syndrome is not initially possible, data suggest starting usual treatment for acute coronary syndrome, suspended upon confirmation of the diagnosis (Prasad et al., 2008; Silva et al., 2009).

Thus, initial management consists in administration of $\beta$-blockers, angiotensinconverting enzyme inhibitors, aspirin and heparin. Congestive heart failure is treated by diuretics (Bybee et al., 2004; Gianni et al., 2006). $\beta$-blockers are recommended in patients with left ventricle outflow tract obstruction and are contraindicated in case of congestive heart failure with low ejection fraction, hypotension or bradycardia. For their part, angiotensinconverting enzyme inhibitors are recommended in patients without a left ventricle outflow tract obstruction. The duration of the treatment remains unclear but it is commonly accepted to continue the treatment until the full recovery of the left ventricle systolic function.

\subsubsection{Hemodynamic compromise}

In the case of hemodynamic compromise due to pump failure, the use of an intra-aortic balloon pump is better than the use of inotropic agents, as these are known to enhance left ventricle outflow tract obstruction (Previtali et al., 2005). Therefore, echocardiography has to be done upon presentation in order to detect left ventricle outflow tract obstruction (Tsuchihashi et al., 2001; Bybee et al., 2004). In patients with hypotension due to pump failure without significant left ventricle outflow tract obstruction proven by echocardiography, a treatment with inotropic agents may be started with caution. Inotropic agents proposed are dobutamine or dopamine. Importantly, in patients with severe hypotension without significant left ventricle outflow tract obstruction but with severe left ventricular dysfunction, the use of an intra-aortic balloon pump is preferred to inotropic agents. Moreover, in patients with hypotension due to pump failure associated with a significant left ventricle outflow tract obstruction proven by echocardiography, a treatment with inotropic agents should not be started and the use of an intra-aortic balloon pump is recommended (Villareal et al., 2001; Sharkey et al., 2005). As mentioned above, $\beta$-blockers are recommended in patients with left ventricle outflow tract obstruction and fluid resuscitation is also recommended in the absence of congestive heart failure (Villareal et al., 2001; Bybee et al., 2004). In case of intolerance or inadequately response to $\beta$-blockers, use of an alpha agonist such as phenylephrine is proposed, used with caution and close monitoring due to its vasocontrictive effects (Reeder et al., 2010).

\subsubsection{Left ventricular thrombus}

Left ventricular thrombus must be detected in the acute phase. Short-term anticoagulation is indicated in this case and also in order to prevent its occurrence in patients with severe left ventricle systolic dysfunction. The anticoagulation is continued until left ventricular systolic 
function improves (Kimura et al., 2007; Haghi et al., 2008). Short-term anticoagulation is also prescribed in case of atrial fibrillation (Kimura et al., 2007).

\subsection{Chronic treatment}

Chronic treatment is rarely detailed and it also remains empirical. Chronic $\beta$-blockers are recommended in order to reduce the recurrence rate, in the absence of contraindications or intolerance (Prasad et al., 2008). However, several studies showed the partial efficacy of this therapy in order to prevent either the first episode or a recurrence of the TTC (Sharkey et al. 2010; Parodi et al., 2010). Aspirin is not maintained even if the patient had a coexisting coronary atherosclerosis and angiotensin-converting enzyme inhibitors are not continued if the patient recovers left ventricle systolic function (Prasad et al., 2008; Bybee et al., 2004).

\section{Pathophysiology}

Several hypotheses have been proposed to explain TTC, but the precise mechanisms remain unclear. These pathophysiological hypotheses include: direct toxic effects of catecholamine excess on cardiomyocytes, coronary artery vasospasm, diffused coronary microvascular dysfunction and left ventricle outflow tract obstruction (Wittstein et al., 2005; Akashi et al., 2010; Nef et al., 2007; Nef et al., 2007; Nef et al., 2009a; Nef et al., 2009b).

\subsection{Catecholamine excess}

Catecholamine excess following an emotional or physical stress is supposed to play an important role in the pathophysiology of the TTC and this mechanism is widely reported. Increased catecholamine levels promote microvascular spasm, damage and hypocontraction of the myocardial muscle responsible for the typical regional wall motion abnormalities. A mouse model demonstrated that catecholamine excess is responsible for a negatively inotropic effect (Heubach et al., 2004).

The analysis of endomyocardial biopsies showed contraction band necrosis and mononuclear cell infiltrate, typically consistent with catecholamine excess. The apex of the left ventricle has an increase density of adrenoreceptors accounting for the apex being the most exposed to the cardiomyopathy. Moreover, there is a difference in the distribution of these adrenoreceptors among persons, which could explain the different variants of TTC (Hurst et al., 2006; Lyon et al., 2008; Litvinov et al., 2009).

This neuro-hormonal hypothesis including catecholamine excess and exaggerated stimulation of the sympathetic nervous system is supported by several studies showing that patients with TTC have supraphysiologic and higher levels of plasma catecholamines than patients with acute coronary syndrome (Wittstein et al., 2005)

Moreover, several cases have been described after administration of exogenous cathecolaminergic agents such as dobutamine (Previtali et al., 2005; Abraham et al., 2009; Cherian et al., 2008; Winogradow et al., 2010). However, other studies have documented no significant elevation in plasma catecholamine levels in TTC patients (Bybee et al., 2004; Gianni et al., 2006; Nef et al., 2007; Tsuchihashi et al., 2001; Kawai et al., 2007; Elesber et al., 2007; Sharkey et al., 2008; Blessing et al., 2007; Sharkey et al., 2007; Fazio et al., 2008). Thus, this pathophysiological mechanism is still debated.

\subsection{Coronary artery vasospasm}

Early reports have showed that TTC may be explained by coronary artery vasospasm, based on studies realising an induction of multi-vessel coronary spasm secondary to intra- 
coronary acetylcholine injection (Dote et al., 1991; Tsuchihashi et al., 2001). In fact, most of the patients in Japanese series exhibit a coronary epicardial spasm but it has been rarely described in the Caucasian population (Tsuchihashi et al., 2001; Kurisu et al., 2002; Bybee et al., 2004; Wittstein et al., 2005; Gianni et al., 2006).

However, the duration of the TTC compared to a classical vasospasm and the regional wall motion abnormalities usually extending beyond a single vessel territory limit this theory of causal mechanism. Indeed, recent reviews consider that this mechanism is unlikely to be the underlying cause of TTC (Prasad et al., 2008; Tsuchihashi et al., 2001; Desmet et al., 2003; Kurisu et al., 2002; Yoshida et al., 2007; Abe \& Kondo, 2003).

\subsection{Coronary microvascular dysfunction}

Largely abnormal coronary microvascular function is another pathophysiological mechanisms proposed. Reduced blood flow rates using TIMI frame count and spontaneous improvement of coronary flow reserve suggest a possible involvement of the microvascular function in the pathophysiology of the TTC (Previtali et al., 2005; Kimura et al., 2007; Haghi et al., 2008; Nef al., 2007; Nef et al., 2009). However, it has not yet been clearly defined whether microvascular dysfunction is a primary or secondary phenomenon (Bybee et al., 2004; Yanagi et al., 2002; Barcin et al., 2003; Kume et al., 2005; Gibson et al., 1996). In fact, the coronary microvascular dysfunction could be the result of various causes, such as direct toxic effects of catecholamine excess and excessive sympathetic response or estrogen depletion (Kaski, 2006).

Anyway, highlighting this pathophysiological mechanism, a recent study has demonstrated the key role of myocardial vasoconstriction in the etiopathogenesis of the TTC. For the authors, the typical regional wall motion abnormalities appear to be secondary to microvascular dysfunction, secondary to coronary microvascular vasoconstriction (Galiuto et al., 2010).

However, data still remain controversial as another study showed that the akinetic territories involved were much larger than those affected by the coronary microvascular dysfunction. For the authors, even if coronary microvascular dysfunction is currently present during the acute phase of TTC, this may not be considered as the only pathophysiological mechanism of the cardiomyopathy (Fazio et al., 2010).

\subsection{Left ventricle outflow tract obstruction}

Left ventricle outflow tract obstruction has also been proposed to contribute to TTC pathogenesis. Published data showed that left ventricle outflow tract obstruction might be present in $11 \%$ of the TTC patients (Nef et al., 2010; el Mahmoud et al., 2008). Moreover, inotropic agents have been reported to induce or worsen left ventricle outflow tract obstruction.

Consequently, such findings support a possible role of the left ventricle outflow tract obstruction in the pathogenesis of the TTC, but this pathogenic mechanism is still under debate.

\subsection{Myocarditis}

Another hypothesis has been proposed as a pathophysiological mechanism: myocarditis. Indeed, some cases have been reported to be associated with cardiotropic viruses (Bahlmann et al., 2007). However, the biopsy analysis of the myocardial muscle and the viral serology do not emphasize this pathophysiological mechanism (Silva et al., 2009; Abe et al., 2003). 


\subsection{Hormonal environment}

Last but not least, the cardiomyopathy usually occurs in postmenopausal women, highlighting the role of the hormonal environment and the protecting role of estrogens (Ueyama et al., 2003; Hinojosa-Laborde et al., 1999; \& Celermajer, 2002; Connelly et al., 2006). A case of TTC was described in a young woman suffering from an estrogen deficiency due to Turner syndrome. The woman had a low level of estrogens, as noted in postmenopausal women, explaining why she was more susceptible to TTC (Sato et al., 2009). Moreover, an animal model with estrogen supplementation showed low occurrence of TTC (Ueyama et al., 2003).

\section{Conclusion}

Tako-Tsubo cardiomyopathy (TTC) is a syndrome which has recently gained increasing consideration. Typical presentation mimics acute coronary syndrome, with acute chest pain and/or dyspnoea, associated to electrocardiographic changes and moderate cardiac biomarkers release. The syndrome is characterized by a reversible left ventricle systolic dysfunction typically involving the apex, but in which coronary lesions are not involved. The transient regional wall motion abnormalities usually extend beyond a single vessel territory.

It is important to note that patients with TTC may exhibit life-threatening acute phase and may require early and aggressive initial management.

The pathophysiology of the syndrome remains still unclear and more research is needed in this area. The diagnosis of TTC is most frequently made during coronary angiography, performed as recommended by the guidelines for the management of acute coronary syndrome.

Patients with TTC may be exposed to inappropriate therapy such as thrombolysis, which may lead to serious complications, given the fact that coronary artery obstruction is not being involved. Thus, a good strategy seems to be the transfer of the patients suspected of TTC to a cardiac catheterization laboratory for emergency coronary angiography.

\section{Acknowledgement}

None of the authors have any conflicts of interest, financial or other disclosures to acknowledge.

\section{References}

Abe, Y.; Kondo, M.; Matsuoka, R.; Araki, M.; Dohyama, K. \& Tanio, H. Assessment of clinical features in transient left

ventricular apical ballooning. Journal of the American College of Cardiology, Vol.41, No.5, (2003), pp.737-742.

Abe, Y. \& Kondo, M. Apical ballooning of the left ventricle: a distinct entity? Heart, Vol.89, No.9, (2003), pp. 974-976.

Abdulla, I.; Kay, S.; Mussap, C.; Nelson, GI.; Rasmussen, HH.; Hansen, PS. \& Ward, MR. Apical sparing in Tako-Tsubo

cardiomyopathy. Internal Medicine Journal, Vol.36, No.7, (2006), pp.414-418. 
Abraham, J.; Mudd, JO.; Kapur, N.; Klein, K.; Champion, HC. \& Wittstein, IS. Stress cardiomyopathy after intravenous

administration of catecholamines and beta-receptor agonists. Journal of the American College of Cardiology, Vol. 53, No.15, (2009), pp. 1320-1325.

Akashi, YJ.; Tejima, T.; Sakurada, H.; Matsuda, H.; Suzuki, K.; Kawasaki, K.; Tsuchiya, K.; Hashimoto, N., Musha, H.,

Sakakibara, M.; Nakazawa, K. \& Miyake F. Left ventricular rupture associated with Takotsubo cardiomyopathy. Mayo Clinic Proceedings Mayo Clinic,Vol.79, No.6, (2004), pp.821-824.

Akashi, YJ.; Musha, H.; Nakazawa, K. \& Miyake, F. Plasma brain natriuretic peptide in Takotsubo cardiomyopathy. QJM: montly journal of the association of physicians, Vol.97, No.9, (2004), pp.599-607.

Akashi, YJ.; Musha, H., Kida, K.; Itoh, K.; Inoue, K.; Kawasaki, K.; Hashimoto, N. \& Miyake, F. Reversible ventricular

dysfunction takotsubo cardiomyopathy. European Journal of Heart Failure, Vol.7, No.7, (2005), pp.1171-1176.

Akashi, YJ.; Goldstein, DS.; Barbaro, G \& Ueyama, T. Takotsubo cardiomyopathy: a new form of acute, reversible heart failure. Circulation, Vol.118, No.25, (2008), pp.27542762.

Akashi, Y.; Nef, H. M.; Möllmann, H. \& Ueyama, T. Stress cardiomyopathy. Annual Reviews of Medecine. Vol.61, (2010),

pp. 271-286

Anand, G.; Gong-Yuan, . \& Dellsperger, KC. Echocardiography in stress cardiomyopathy and acute LVOT obstruction. The International Journal of Cardiovascular Imaging, Vol.26, No.5, (2010), pp.527-535.

Bahlmann, E.; Schneider, C.; Krause, K.; Pankuweit, S.; Harle, T. \& Kuck, KH. Tako-Tsubo cardiomyopathy (apical

ballooning) with parvovirus B19 genome in endomyocardial biopsy. International Journal of Cardiology, Vol.116, No.1, (2007), pp.18-21.

Barcin, C.; Denktas, AE.; Garratt, KN. ; Higano, ST.; Holmes, DR. \& Lerman, A. Relation of Thrombolysis in Myocardial

Infarction (TIMI) frame count to coronary flow parameters. The American Journal of Cardiology, Vol.91, No.4, (2003), pp.466-469.

Barrera-Ramirez, CF.; Jimenez-Mazuecos, JM. \& Alfonso, F. Apical thrombus associated with left ventricular apical

ballooning. Heart, Vol.89, No.8, (2003), pp.927.

Bielecka-Dabrowa, A.; Mikhailidis, DP.; Hannam, S.; Rysz, J.; Michalska, M.; Akashi, JA. \& Banach, M. Takotsubo cardiomyopathy - The current state of knowledge. International Journal of Cardiology, Vol.142, No.2, (2010), pp.120-125.

Blessing, E.; Steen, H.; Rosenberg, M.; Katus, H. \& Frey, N. Recurrence of Takotsubo cardiomyopathy with variant forms

of left ventricular dysfunction. Journal of the American Society Echocardiography, Vol.439, No.4, (2007), pp.11-12. 
Bonello, L.; Com, O.; Ait-Moktar, O.; Theron, A.; Moro, PJ.; Salem, A.; Sbragia, P. \& Paganelli, F. Ventricular arrhythmias

during Takotsubo syndrome. International Journal of Cardiology, Vol.128, No.2, (2008), pp.5053.

Brandspiegel, HZ.; Marinchak, RA.; Rials, SJ. \& Kowey PR. A broken heart. Circulation, Vol.98, No.13, (1998), pp.1349.

Bybee, KA.; Prasad, A.; Barsness, GW.; Lerman, A.; Jaffe, AS.; Murphy, JG.; Wright, RS. \& Rihal, CS. Clinical characteristics and thrombolysis in myocardial infarction frame counts in women with transient left ventricular apical ballooning syndrome. The American Journal of Cardiology, Vol.94, No.3, (2004), pp.343-346.

Bybee, KA. ; Kara, T. ; Prasad, A.; Lerman, A.; Barsness, GW.; Wright, RS.\& Rihal, CS. Systematic review: transient left ventricular apical ballooning: a syndrome that mimics St segment elevation myocardial infarction. Annals of Internal Medicine, Vol.141, No.11, (2004), pp. 858-865.

Bybee, KA.; Motiei, A.; Syed, IS.; Kara, T.; Prassad, A.; Lennon, RJ.; Murphy, JG.; Hammill, SC.; Rihal, CS.\& Wright, RS. Electrocardiography cannot reliably differentiate transient left ventricular apical ballooning syndrome from anterior ST-segment elevation myocardial infarction. Journal of Electrocardiology, Vol.40, No.1, (2007), pp.1-6.

Cherian, J.; Kothari, S.; Angelis, D.; Atef, A.; Downey, B.\& Kirkpatrick, J. Atypical takotsubo cardiomyopathy:

dobutamine-precipitated apical ballooning with left ventricular outflow tract obstruction. Texas Heart Institute Journal, Vol.35, No.1, (2008), pp.73-75.

Citro, R.; Pascotto, M.; Provenza, G.; Gregorio, G.\& Bossone, E. Transient left ventricular ballooning (tako-tsubo cardiomyopathy) soon after intravenous ergonovine injection following caesarean delivery. International Journal of Cardiology, Vol.138, No.2, (2010), pp.31-34.

Citro, R.; Caso, I.; Provenza, G.; Santoro, M.; Gregorio, G. \& Bossone, E. Right Ventricular Involvement and Pulmonary Hypertension in an Elderly Woman With Tako-Tsubo Cardiomyopathy. Chest, Vol.137, No.4, (2010), pp.973-975.

Connelly, K.; MacIsaac, A. \& Jelinek, MV. The "tako-tsubo" phenomenon and myocardial infarction. Southern Medical Journal, Vol.99, No.1, (2006), pp.2-3.

Crimi, E.; Baqqish, A.; Leffert, L.; Plan-Smith, MC.; Januzzi, JL. \& Jlang, Y. Acute reversible stress-induced cardiomyopathy associated with cesarean delivery under spinal anesthesia. Circulation, Vol.117, No.23, (2008), pp.3052-3053.

De Gregorio, C.; Grimaldi, P. \& Lentini, C. Left ventricular thrombus formation and cardioembolic complications in patients with takotsubo-like syndrome: a systematic review. International Journal of Cardiology, Vol.131, No.1, (2008), pp.18-24.

Daka, MA.; Khan, RS. \& Deppert, EJ. Transient left ventricular apical ballooning after a cocaine binge. Journal of Invasive Cardiology, Vol.19, No.12, (2007), pp.378-380.

Dec, GW. Recognition of the apical ballooning syndrome in the United States. Circulation, Vol.111, No.4, (2005), pp.388-390.

Deetjen, AG.; Conradi, G.; Mollmann, S.; Rad, A.; Hamm, CW. \& Dill T. Value of gadoliniumenhanced magnetic resonance imaging in patients with Tako-Tsubo- 
like left ventricular dysfunction. Journal of Cardiovascular Magnetic Resonance, Vol.8, No.2, (2006), pp.367-372.

Denney, SD.; Lakkireddy, DR. \& Khan, IA. Long QT syndrome and torsade de pointe in transient left ventricular apical ballooning syndrome. International Journal of Cardiology, Vol.100, No.3, (2005), pp.499-501.

Desmet, WJ.; Adriaenssens, BF. \& Dens, JA. Apical ballooning of the left ventricle: first series in white patients. Heart, Vol.89, No.9, (2003), pp.1027-1031.

Dib, C.; Prasad, A.; Friedman, PA.; Ahmad, E.; Rihal, CS.; Hammill, SC. \& Asirvatham, SJ. Malignant arrhythmia in apical ballooning syndrome: risk factors and outcomes. Indian Pacing and Electrophysiology Journal, Vol. 8, No. 3, (2008), pp.182-192.

Dib, C.; Asirvatham, S.; Elesber, A.; Rihal, C.; Friedman, P. \& Prassad, A. Clinical correlates and prognostic significance of electrocardiographic abnormalities in apical ballooning syndrome (Takotsubo/stress-induced cardiomyopathy). American Heart Journal, Vol.157, No.5, (2009), pp.933-938.

Donohue, D. \& Movahed, MR. Clinical characteristics, demographics and prognosis of transient left ventricular apical ballooning syndrome. Heart Failure Reviews. Vol.10, No.4, (2005), pp. 311-316.

Dorfman, T.; Aqel, R.; Allred, J.; Woodham, R. \& Iskandrian AE. Takotsubo cardiomyopathy induced by treadmill exercise testing: an insight into the pathophysiology of transient left ventricular apical (or midventricular) ballooning in the absence of obstructive coronary artery disease. Journal of the American College of Cardiology, Vol.49, No.11, (2007), pp.1223-1225.

Dote, K.; Sato, H.; Tateishi, H.; Uchida, T. \& Ishihara, M. Myocardial stunning due to simultaneous multivessel coronary spasms: a review of 5 cases. Journal of Cardiology, Vol.21, No.2, (1991), pp.203-214.

El Mahmoud, R.; Mansencal, N.; Pillère, R. ; Leyer, F. ; Abbou, N. ; Michaud, P. ; Nallet, O. ; Digne, F. ; Lacombe, P. ; Cattan, S. \& Dubourg, O. Prevalence and characteristics of left ventricular outflow tract obstruction in Tako-Tsubo syndrome. American Heart Journal, Vol.156, No.3, (2008), pp.543-548.

Elesber, AA.; Prasad, A.; Bybee, KA.; Valeti, U.; Motiel, A.; Lerman, A.; Chandrasekaran, K.; \& Rihal, CS. Transient cardiac apical ballooning syndrome: prevalence and clinical implications of right ventricular involvement. Journal of the American College of Cardiology, Vol. 47, No.5, (2006), pp.1082-1083.

Elesber, AA.; Prasad, A.; Lennon, RJ.; Wright, RS.; Lerman, A \& Rihal, CS. Four-year recurrence rate and prognosis of the apical ballooning syndrome. Journal of the American College of Cardiology, Vol.50, No.5, (2007), pp.448-452.

Elkhateeb, OE. \& Beydoun, HK. Recurrent long QT syndrome and syncope in transient apical ballooning syndrome (takotsubo cardiomyopathy). The Canadian Journal of Cardiology, Vol.24, No.12, (2008), pp.917-919.

Fazio, G.; Pizzuto, C.; Barbaro, G.; Sutera, L.; Incalcaterra, E.; Evola, G.; Azzarelli, S.; Palecek, T.; Di Gesaro, G.; Cascio, C.; Novo, G.; Akashi, YJ. \& Novo, S. Chronic pharmacological treatment in Takotsubo cardiomyopathy. International Journal of Cardiology, Vol.127, No.1, (2008), pp.121-123 
Fazio, G.; Sarullo, FM.; Novo, G.; Evola, S.; Lunetta, M.; Barbaro, G.; Sconci, F.; Azzarelli, S.; Akashi, Y.; Fedele, F. \& Novo, S. Tako-Tsubo cardiomyopathy and microcirculation. Journal of Clinical Monitoring and Computing, Vol.24, No.2, (2010), pp.101-105.

Fineschi, V.; Michalodimitrakis, M.; D’Errico, S.; Neri, M.; Pomara, C.; Riezzo, I. \& Turillazzi. E. Insight into stress-induced cardiomyopathy and sudden cardiac death due to stress. A forensic cardio-pathologist point of view. Forensic Science International, Vol.194, No. 1-3, (2010), pp.1-8.

Flavahan, NA. A farewell kiss triggers a broken heart? Circulation Research, Vol.98, No.9, (2006), pp.1117-1119.

Gallerani, M.; Manfredini, R.; Ricci, L.; Grandi, E.; Cappato, R.; Calö, G.; Pareschi, PL. \& Fersini, C. Sudden death from pulmonary thromboembolism: chronobiological aspects. European Heart Journal, Vol.13, No. 5, (1992), pp.661-665.

Galiuto, L.; De Caterina, AR.; Porfidia, A.; Paraggio, L.; Barchetta, S.; Locorotondo, G.; Rebuzzi, AG. \& Crea, F. Reversible coronary microvascular dysfunction: a common pathogenetic mechanism in Apical Ballooning or Tako-Tsubo Syndrome. European Heart Journal, Vol.31, No.11, (2010), pp.1319-1327.

Gavish, D.; Rozenman, Y.; Hafner, R.; Bartov, E. \& Ezri, T. Takotsubo cardiomyopathy after general anesthesia for eye surgery. Anesthesiology, Vol.105, No.3, (2006), pp.621-623.

Gianni, M.; Dentali, F.; Grandi, AM.; Sumner, G.; Hiralal, R. \& Lonn, E. Apical ballooning syndrome or takotsubo cardiomyopathy: a systemic review. European Heart Journal, Vol.27, No.13, (2006), pp.1523-1529.

Gibson, CM.; Cannon, CP.; Daley, WL.; Dodge, JT Jr.; Alexander, B Jr.; Marble, SJ.; McCabe, CH.; Raymond, L.; Fortin, T.; Poole, WK. \& Braunwald, E. TIMI frame count: a quantitative method of assessing coronary artery flow. Circulation, Vol.93, No.5, (1996), pp.879-888.

Hachamovitch, R.; Chang, JD.; Kuntz, RE.; Papageorgiu, P.; Levin, MS. \& Goldberger, AL. Recurrent reversible cardiogenic shock triggered by emotional distress with no obstructive coronary disease. American Heart Journal, Vol.129, No.5, (1995), pp.10261028.

Haghi, D.; , Athanasiadis, A. ; Papavassiliu, T. ; Suselbeck, T.; Fluechter, S.; Mahrholdt, H.; Borggrefe, M. \& Sechtem, U. Right ventricular involvement in Takotsubo cardiomyopathy. European Heart Journal, Vol.27, No.20, (2006), pp.2433-2439.

Haghi, D.; Fluechter, S.; Suselbeck, T.; Saur, J.; Bheleel, O.; Borggrefe, M. \& Papavassiliu, T. Takotsubo cardiomyopathy (acute left ventricular apical ballooning syndrome) occurring in the intensive care unit. Intensive Care Medecine, Vol.32, No.7, (2006), pp.1069-1074.

Haghi, D.; Fluechter, S.; Suselbeck, T.; Kaden, JJ.; Borggrefe, M. \& Papavassiliu, T. Cardiovascular magnetic resonance findings in typical versus atypical forms of the acute apical ballooning syndrome (Takotsubo cardiomyopathy). International Journal of Cardiology, Vol.120, No.2, (2007), pp.205-211.

Haghi, D.; Papavassiliu, T.; Heggemann, F.; Kaden, JJ.; Borggrefe, M. \& Suselbeck, T. Incidence and clinical significance of left ventricular thrombus in tako-tsubo 
cardiomyopathy assessed with echocardiography. QJM: monthly Journal of the Association of Physicians, Vol.101, No.5, (2008), pp.381-386.

Hahn, JY.; Gwon, HC.; Park, SW.; Chol, SH.; Chol, JH.; Chol, JO.; Lee, SC.; On, YK.; Kim, JS.; Kim, DK.; Jeon, ES.; Lee, SH.; Hong, KP. \& Park, JE. The clinical features of transient left ventricular nonapical ballooning syndrome: comparison with apical ballooning syndrome. American Heart Journal, Vol.154, No.6, (2007), pp.1166-1173.

Hawthorne, L. \& Lyons, G. Cardiac arrest complicating spinal anaesthesia for cesarean section. International Journal of Obstetric Anesthesia, Vol.6, No.2, (1997), pp.126-129

Heubach, JF.; Ravens, U. \& Kaumann, AJ. Epinephrine activates both Gs and Gi pathways, but norepinephrine activates only the Gs pathway through human beta2adrenoceptors overexpressed in mouse heart. Molecular Pharmacology, Vol.65, No.5, ( 2004), pp.1313-1322.

Hinojosa-Laborde, C.; Chapa, I.; Lange, D. \& Haywood, JR. Gender differences in sympathetic nervous system regulation. Clinical and Experimental Pharmacology $\mathcal{E}$ Physiology, Vol.26, No.2, (1999), pp.122-126.

Hoyt, J.; Lerman, A.; Lennon, RJ. ; Rihal, CS. \& Prasad, A. Left anterior descending artery length and coronary atherosclerosis in apical ballooning syndrome (Takotsubo/stress induced cardiomyopathy). International Journal of Cardiology, Vol.145, No.1, (2010), pp.112-115.

Hurst, RT.; Askew, JW.; Reuss, CS.; Lee, RW.; Sweeney, JP.; Fortuln, FD.; Oh, JK \& Tajik, AJ. Transient midventricular ballooning syndrome: a new variant. Journal of the American College of Cardiology, Vol.48, No.3, (2006), pp.579-583.

Hurst, RT.; Prasad, A.; Askew, JW.; Sengupta, PP. \& Tajik, AJ. Takotsubo Cardiomyopathy: A Unique Cardiomyopathy With Variable Ventricular Morphology. JACC. Cardiovascular Imaging, Vol.3, No.6, (2010), pp.641-649.

Ionescu, CN.; Aguilar-Lopez, CA.; Sakr, AE.; Ghantous, AE. \& Donohue, TJ. Long-term Outcome of Tako-tsubo Cardiomyopathy. Heart, Lung and Circulation, Vol.19, No.10, (2010), pp.601-605.

Itoh, H.; Miyake, Y.; Hioki, I.; Tanaka, S. \& Okabe, M. Report of Takotsubo cardiomyopathy occurring during cardiopulmonary bypass. The Journal of Extra-Corporeal Technology, Vol.39, No.2, (2007), pp.109-111.

Jabaudon, M.; Bonnin, M.; Bolandard, F.; Chanseaume, S.; Dauphin, C. \& Bazin, JE. Takotsubo syndrome during induction of general anesthesia. Anaesthesia, Vol.62, No.5, (2007), pp.519-523.

Kawai, S.; Suzuki, H.; Yamaguchi, H.; Tanaka, K.; Sawada, H.; Aizawa, T.; Watanabe, M.; Tamura, T.; Umawatari, K.; Kawata, M.; Nakamura, T.; Yamanaka, O. \& Okada, R. Ampulla cardiomyopathy ('takotsubo' cardiomyopathy): reversible left ventricular dysfunction with ST segment elevation. Japanese Circulation Journal, Vol.64, No.2, (2000), pp.156-159.

Kaski, JC. Cardiac syndrome $X$ in women: the role of oestrogen deficiency. Heart, Vol. 92, No.S3, (2006), pp.5-9.

Kawai, S.; Kitabatake, A.; Tomoike, H. \& Takotsubo Cardiomyopathy Group. Guidelines for diagnosis of Takotsubo (ampulla) cardiomyopathy. Circulation Journal, Vol.71, No.6, (2007), pp.990-992. 
Kim, S.; Yu, A.; Filippone, LA.; Kolansky, DM \& Raina, A. Inverted Takotsubo Pattern Cardiomyopathy Secondary to Pheochromocytoma: A Clinical Case and Literature Review. Clinical Cardiology, Vol.33, No.4, (2010), pp.200-205.

Kimura, K.; Tanabe-Hayashi, Y.; Noma, S. \& Fukuda, K. Rapid formation of left ventricular giant thrombus with Takotsubo cardiomyopathy. Circulation, Vol.115, No.23, (2007), pp.620-621.

Klinčeva, M.; Widimský, P.; Pešl, L.; Stásek, J.; Tousek, F.; Vambera, M. \& Bílková D. Prevalence of stress-induced myocardial stunning (Tako-Tsubo cardiomyopathy) among patients undergoing emergency coronary angiography for suspected acute myocardial infarction. International Journal of Cardiology, Vol.120, No.3, (2007), pp.411-413.

Kolkebeck, TE.; Cotant, CL. \& Krasuski, RA. Takotsubo cardiomyopathy: an unusual syndrome mimicking an ST-elevation myocardial infarction. The American Journal of Emergency Medicine, Vol.25, No.1, (2007), pp.92-95.

Krishnan, U.; Zacharzewski, A. \& Schmitt, M. Nonapical Tako-tsubo Cardiomyopathy Associated with Coronary Slow Flow: A Case Report and Review of the Literature. Clinical Cardiology, Vol.32, No.11, (2009), pp.63-66.

Kume, T.; Akasaka, T.; Kawamoto, T.; Yoshitani, H.; Watanabe, N.; Neishi, Y.; Wada, N. \&Yoshida, K. Assessment of coronary microcirculation in patients with takotsubolike left ventricular dysfunction. Circulation Journal, Vol.69, No.8, (2005), pp.934939.

Kurisu, S.; Sato, H.; Kawagoe, T.; Ishihara, M.; Shimatani, Y.; Nishioka, K.; Kono, Y.; Umemura, T. \& Nakamura, S. Tako-tsubo-like left ventricular dysfunction with STsegment elevation: a novel cardiac syndrome mimicking acute myocardial infarction. American Heart Journal, Vol.143, No.3, (2002), pp.448-455.

Kurisu, S.; Inoue, I.; Kawagoe, T.; Ishihara, M.; Shimatani, Y.; Nakamura, S.; Yoshida, M.; Mitsuba, N.; Hata, T. \& Sato H. Time course of electrocardiographic changes in patients with Tako-Tsubo syndrome: comparison with acute myocardial infarction with minimal enzymatic release. Circulation Journal, Vol.68, No.1, (2004), pp.77-81.

Kurowski, V.; Kaiser, A.; von Hof, K.; Killermann, DP.; Mayer, B.; Hartmann, F.; Schunkert, H. \& Radke PW. Apical and midventricular transient left ventricular dysfunction syndrome (tako-tsubo cardiomyopathy): frequency, mechanisms, and prognosis. Chest, Vol.132, No.3, (2007), pp.809-816.

Lamm, G.; Auer, J. \& Eber, B. Atypical form of left ventricular ballooning after a violent attack. International Journal of Cardiology; Vol.119, No.3, (2007), pp.395-397.

Lentschener, C.; Vignaux, O.; Spaulding, C.; Bonnichon, P.; Legmann, P. \& Ozier, Y. Early postoperative Takotsubo-like left ventricular dysfunction: transient left ventricular apical ballooning syndrome. Anesthesia and Analgesia, Vol.103, No.3, (2006), pp.580582.

Littlejohn, F.; Syed, O.; Ornstein, E.; Connolly, ES. \& Heyer, EJ. Takotsubo cardiomyopathy associated with anesthesia: three case reports. Cases Journal, Vol.1, No.1, (2008), pp.227. 
Liu, S.; Bravo-Fernandez, C.; Riedl, C.; Antapli, M. \& Dhamee, MS. Anesthetic management of Takotsubo cardiomyopathy: general versus regional anesthesia. Journal of Cardiothoracic and Vascular Anesthesia, Vol.22, No.3, (2008), pp.438-441.

Liu, S. \& Saeed Dhamee M. Perioperative transient left ventricular apical ballooning syndrome: Takotsubo cardiomyopathy: a review. Journal of Clinical Anesthesia, Vol.22, No.1, (2010), pp.64-70.

Litvinov, IV.; Kotowycz, MA. \& Wassmann, S. Iatrogenic epinephrine-induced reverse takotsubo cardiomyopathy: direct evidence supporting the role of catecholamines in the pathophysiology of the "broken heart syndrome". Clinical Research in Cardiology, Vol.98, No.7, (2009), pp.457-462.

Lyon; AR.; Rees, PS.; Prasad, S.; Poole-Wilson, PA. \& Harding, SE. Stress (Takotsubo) cardiomyopathy - a novel pathophysilogical hypothesis to explain catecholamineinduced acute myocardial stunning. Nature Clinical Practice. Cardiovascular Medicine, Vol.5, No.1, (2008), pp.22-29.

Manfredini, R.; Citro, R.; Previtali, M.; Vriz, O.; Ciampi, Q.; Pascotto, M.; Tagliamonte, E.; Provenza, G.; Manfredini, F. \& Bossone, E. Monday preference in onset of takotsubo cardiomyopathy. The American Journal of Emergency Medicine. Vol.28, No, 6, (2010), pp.715-719.

Mansencal, N.; El Mahmoud, R. \& Dubourg, O. Occurrence of Tako-Tsubo Cardiomyopathy and Chronobiological Variation. Journal of the American college of Cardiology, Vol.55, No.5, (2010), pp.5499-5506.

Mansencal, N.; Abbou, N.; N'Guetta, R.; Pillière, R.; El Mahmoud, R. \& Dubourg, O. Apicalsparing variant of Tako-Tsubo cardiomyopathy: Prevalence and characteristics. Archives of Cardiovascular Disease. Vol.103, No.2, (2010), pp.75-79

Mariscalco, G.; Cattaneo, P.; Rossi, A.; Baravelli, M.; Piffaretti, G.; Scannapieco, A.; Nassiacos, D. \& Sala, A. Tako-tsubo cardiomyopathy complicated by ventricular septal perforation and septal dissection. Heart and Vessels, Vol.25, No.1, (2010), pp.73-75.

Maron, BJ.; Towbin, JA.; Thiene, G.; Antzelevitch, C.; Corrado, D.; Arnett, D.; Moss, AJ.; Seidman, CE. \& Young, JB. Contemporary definitions and classification of the cardiomyopathies. Circulation, Vol.113, No.14, (2006), pp.1807-1816.

Matsuoka, H.; Kawakami, H.; Koyama, Y.; Inoue, K.; Nishimura, K.; Saeki, H. \& Ito, T. Tako tsubo cardiomyopathy with a significant pressure gradient in the left ventricle. Heart and Vessels, Vol.15, No.4, (2000), pp.203

Matsuoka, K.; Okubo, S.; Fujii, E.; \& Uhida, F. Evaluation of the arrhythmogenecity of stressinduced "Takotsubo cardiomyopathy" from the time course of the 12-lead surface electrocardiogram. The American Journal of Cardiology, Vol.92, No.2, (2003), pp.230233.

Mazzarotto, P.; Stecconi, P.; Gemelli, F.; Azzarito, M. \& Farnetti, F. A case of ballooning syndrome with atypical anterior localization. Italian Heart Journal, Vol.6, No.11, (2005), pp.730-734

Mitchell, JH.; Hadden, TB.; Wilson, JM.; Achari, A.; Muthupillai, R. \& Flamm, SD. Clinical features and usefulness of cardiac magnetic resonance imaging in assessing myocardial viability and prognosis in Takotsubo cardiomyopathy (transient left 
ventricular apical ballooning syndrome). The American Journal of Cardiology, Vol.100, No.2, (2007), pp.296-301.

Mizutani, K. \& Okada, M. A case of intraoperative repeated coronary artery spasm with STsegment depression. Masui, Vol.51, No.10, (2002), pp.1114-1116.

Montassier, E.; Gueffet, JP.; Trewick, D.; Le Conte, P. \& Potel, G. À propos d'un cas de syndrome de Tako-Tsubo ou comment une situation stressante peut vous amener en salle de coronarographie... Journal Européen des Urgences, Vol.22, No.4, (2009), pp.114-117.

Movaheda, MR. \& Donohueb, D. Review: transient left ventricular apical ballooning, broken heart syndrome, ampulla cardiomyopathy, atypical apical ballooning, or TakoTsubo cardiomyopathy. Cardiovascular Revascularization Medicine, Vol.8, No.4, (2007), pp. 289-292.

Mudd, JO.; Kapur, NK.; Champion, HC.; Schulman, SP. \& Wittstein, IS. Patients with stressinduced (takotsubo) cardiomyopathy have an increased prevalence of mood disorders and antidepressant use compared to patients with acute myocardial infarction. Journal Cardiac Failure, Vol.13, No.6, (2007), pp.176.

Muller, O.; Roguelov, C. \& Pascale P. A basal variant form of the transient 'midventricular' and 'apical' ballooning syndrome. QJM: montly journal of the association of physicians. Vol.100, No.11, (2007), pp.738-739.

Novak, G.; Kross, K.; Follmer, K.; Brofferio, A. \& Shirani J. Transient biventricular apical ballooning: a unique presentation of the "broken heart.", Clinical Cardiology, Vol.30, No7, (2007), pp.355-358.

Nef, HM.; Möllmann, H.; Sperzel, J.; Weber, M.; Brück, H.; Hamm, CW. \& Elsässer A. Temporary third-degree atrioventricular block in a case of apical ballooning syndrome. International Journal of Cardiology, Vol.113, No.2, (2006), pp.33-35.

Nef, HM.; Möllmann, H.; Kostin, S.; Troidl, C.; Voss, S.; Weber, M.; Dill, T.; Rolf, A.; Brandt, R.; Hamm, CW. \& Elsässer A. Tako-Tsubo cardiomyopathy: intraindividual structural analysis in the acute phase and after functional recovery. European Heart Journal, Vol.28, No.20, (2007), pp.2456-2464.

Nef, HM.; Möllmann, H. \& Elsässer, A. Tako-tsubo cardiomyopathy (apical ballooning). Heart, Vol.93, No.10, (2007), pp.1309-1315.

Nef, HM.; Möllmann, H.; Hilpert, P.; Masseli, F.; Troidl, C.; Rolf, A.; Dill, T.; Skwara, W.; Weber, M.; Hamm, C. \& Elsässer, A. Severe mitral regurgitation in Tako-Tsubo cardiomyopathy. International Journal of Cardiology, Vol.132, No.2, (2009), pp.77-79.

Nef, HM.; Möllmann, H.; Troidl, C.; Kostin, S.; Voss, S.; Hilpert, P.; Behrens, CB.; Rolf, A.; Rixe, J.; Weber, M.; Hamm, CW. \& Elsässer, A. Abnormalities in intracellular Ca2+ regulation contribute to the pathomechanism of Tako-Tsubo cardiomyopathy. European Heart Journal, Vol.30, No.17, (2009), pp.2155-2164.

Nef, HM.; Möllmann, H.; Hilpert, P.; Troidl, C.; Voss, S.; Rolf, A.; Behrens, CB.; Weber, M.; Hamm, CW. \& Elsässer, A. Activated cell survival cascade protects cardiomyocytes from cell death in Tako-Tsubo cardiomyopathy. European Journal of Heart Failure, Vol.11, No.8, (2009), pp.758-764.

Nef, HM.; Möllmann, H.; Akashi, YJ. \& Hamm, CW. Mechanisms of stress (Takotsubo) cardiomyopathy. Nature Reviews. Cardiology, Vol.7, No.4, (2010), pp.187-193. 
Ohara, Y.; Hiasa, Y.; Hosokawa, S.; Tomokane, T.; Yamaguchi, K.; Ogura, R.; Miyajima, H.; Ogata, T.; Yuba, K.; Suzuki, N.; Takahashi, T.; Kishi, K. \& Ohtani R. Left ventricular free wall rupture in transient left ventricular apical ballooning. Circulation Journal, Vol.69, No.8, (2005), pp.621-623.

Ogura, R.; Hiasa, Y.; Takahashi, T.; Yamaguchi, K.; Fujiwara, K.; Ohara, Y.; Nada, T; Ogata, T.; Kusunoki, K.; Yuba, K.; Hosokawa, S.; Kishi, K. \& Ohtani, R. Specific findings of the standard 12-lead ECG in patients with 'Takotsubo' cardiomyopathy: comparison with the findings of acute anterior myocardial infarction. Circulation Journal, Vol.67, No.8, (2003), pp.687-90.

Ohtsubo, M.; Sakai, H.; Takano, H.; Kon, H.; Okamoto, K.; Yoshida, N. \& Fujita, M. Atypical takotsubo cardiomyopathy with preservation of apical contraction: a case report including pathological findings. Journal of Cardiology, Vol.46, No.6, (2005), pp.237242.

Del Pace, SD.; Parodi, G.; Bellandi, B.; Zampini, L.; Venditti, F.; Ardito, M.; Antoniucci, D. \& Gensini GF. Anxiety trait in patients with stress-induced cardiomyopathy: a casecontrol study. Clinical Research in Cardiology, (2011).

Park, JH.; Kang, SJ.; Song, JK.; Kim, HK.; Lim, CM.; Kang, DH. \& Koh, Y. Left ventricular apical ballooning due to severe physical stress in patients admitted to the medical ICU. Chest, Vol.28, No.1, (2005), pp.296-302.

Parodi, G.; Del Pace, S.; Carrabba, N.; Salvadori, C.; Memisha, G.; Simonetti, I.; Antoniucci, D. \& Gensini, GF. Incidence, clinical findings, and outcome of women with left ventricular apical ballooning syndrome. The American Journal of Cardiology, Vol.99, No.2, (2007), pp.182-185.

Parodi, G. \& Antoniucci, D. Transient left ventricular apical ballooning syndrome after inadvertent epidural administration of potassium chloride. International Journal of Cardiology, Vol.124, No.1, (2007), pp.14-15

Pavin, D.; Le Breton, H. \& Daubert, C. Human stress cardiomyopathy mimicking acute myocardial syndrome. Heart, Vol.78, No.5, (1997), pp.509-511.

Pernicova, I.; Garg, S.; Bourantas, C.; Alamgir, F. \& Hoye, A. Takotsubo cardiomyopathy: a review of the literature. Angiology, Vol.61, No.2, (2010), pp.166-173.

Pilgrim, TM. \& Wyss, TR. Takotsubo cardiomyopathy or transient left ventricular apical ballooning syndrome: A systematic review. International Journal of Cardiology, Vol.124, No.3, (2008), pp. 283-292.

Pilliere, R. ; Mansencal, N. ; Digne, F.; Lacombe, P.; Joseph, T.; \& Dubourg, O. Prevalence of takotsubo syndrome in a large urban agglomeration. The American Journal of Cardiology, Vol.98, No.5, (2006), pp.662-665.

Prasad A. Apical ballooning syndrome: an important differential diagnosis of acute myocardial infarction. Circulation, Vol.115, No.5, (2007), pp.56-59.

Prasad, A.; Lerman, A. \& Rihal, CS. Apical ballooning syndrome (Tako-Tsubo or stress cardiomyopathy): a mimic of acute myocardial infarction. American Heart Journal, Vol.155, No.3, (2008), pp.408-417.

Previtali, M.; Repetto, A. \& Scuteri, L. Dobutamine induced severe midventricular obstruction and mitral regurgitation in left ventricular apical ballooning syndrome. Heart, Vol.91, No.3, (2005), pp.353. 
Rajani, R.; Przedlacka, A.; Saha, M. \& de Belder, A. Pancreatitis and the broken heart. European Journal of Emergency Medicine, Vol.17, No.1, (2010), pp.27-29.

Ramakrishna, G.; Ravi, BS. \& Chandrasekaran, K. Apical ballooning syndrome in a postoperative patient with normal microvascular perfusion by myocardial contrast echocardiography. Echocardiography, Vol.22, No.7, (2005), pp.606-610.

Reeder, GS. \& Prasad, A. In: Uptodate, 1.04.2011. Available from Stress-induced (takotsubo) cardiomyopathy http://www.uptodate.com/contents/stress-induced-takotsubocardiomyopathy.

Reuss, CS.; Lester, SJ.; Hurst, RT.; Askew, JW.; Nager, P.; Lusk, J.; Altemose, GT. \& Tajik, AJ. Isolated left ventricular basal ballooning phenotype of transient cardiomyopathy in young women. The American Journal Cardiology, Vol.99, No.10, (2007), pp.14511453.

Rivera, JM.; Locketz, AJ.; Fritz, KD.; Horlocker, TT.; Lewallen, DG.; Prasad, A.; Bresnahan, JF. \& Kinney, MO. "Broken heart syndrome" after separation (from OxyContin). Mayo Clinic Proceedings Mayo Clinic, Vol.81, No.6, (2006), pp.825- 828.

Rossor, AM.; Pearce, SH. \& Adams, PC. Left ventricular apical ballooning (Takotsubo cardiomyopathy) in thyrotoxicosis. Thyroid, Vol.17, No.2, (2007), pp.181-182.

Rostoff, P.; Latacz, P.; Piwowarska, W.; Konduracka, E.; Bolech, A. \& Zmudka, K. Transient ST-segment elevation in lead aVR associated with tako-tsubo cardiomyopathy. International Journal of Cardiology, Vol.134, No.3, (2009), pp.97-110.

Sader, MA. \& Celermajer, DS. Endothelial function, vascular reactivity and gender differences in the cardiovascular system. Cardiovascular Research, Vol.53, No.3, (2002), pp.597-604.

Sakai, K.; Ochiai, H.; Katayama, N.; Nakamura, K.; Arataki, K.; Kido, T.; Iwamoto, H.; Nakamura, S. \& Nakamishi, T. A serious clinical course of a very elderly patient with takotsubo cardiomyopathy. Heart and Vessels, Vol. 20, No.2, (2005), pp.77-81

Sato, H.; Tateishi, H. \& Uchida, T. Takotsubo-type cardiomyopathy due to multivessel spasm. In: Clinical aspect of myocardial injury: From ischemia to heart failure, Kodama, K.; Haze, K.; Hon, M., Kagakuhyouronsha, (1990).

Sato, M.; Fujita, S.; Saito, A.; Ikeda, Y.; Kitazawa, H.; Takahashi, M.; Ishiguro, J.; Okabe, M.; Nakamura, Y.; Nagai, T.; Watanabe, H.; Kodama, M. \& Aizawa, Y. Increased incidence of transient left ventricular apical ballooning; (so-called 'Takotsubo' cardiomyopathy) after the mid-Niigata Prefecture earthquake. Circulation journal, Vol.70, No.8, (2006), pp.947-953.

Sato, A.; Yagihara, N.; Kodama, M.; Mitsuma, W.; Tachikawa, H.; Ito, M.; Hanawa, H. \& Aizawa, Y. Takotsubo cardiomyopathy after delivery in an oestrogen-deficient patient. International Journal of Cardiology, (2009).

Sharkey, SW.; Lesser, JR.; Zenovich, AG.; Maron, MS.; Lindberg, J.; Longe, TF. \& Maron, BJ. Acute and reversible cardiomyopathy provoked by stress in women from the United States. Circulation, Vol.111, No.4, (2005), pp.472-479.

Sharkey, SW.; Lesser, JR.; Maron, MS. \& Maron, BJ. Stress cardiomyopathy. Journal of the American College of Cardiology, Vol. 49, No8, (2007), pp.921.

Sharkey, SW.; Lesser, JR.; Menon, M.; Parpart, M.; Maron, MS. \& Maron, BJ. Spectrum and significance of electrocardiographic patterns, troponin levels, and thrombolysis in 
myocardial infarction frame count in patients with stress (tako-tsubo) cardiomyopathy and comparison to those in patients with ST-elevation anterior wall myocardial infarction. The American Journal of Cardiology, Vol.101, No.12, (2008), pp.1723-1728.

Sharkey, SW.; Windenburg, DC.; Lesser, JR.; Maron, MS.; Hauser, RG.; Lesser, JN.; Haas, TS.; Hodges, JS. \& Maron, BJ. Natural history and expansive clinical profile of stress (tako-tsubo) cardiomyopathy. Journal of the American College of Cardiology, Vol.55, No.4, (2010), pp.333-341.

Silva, C.; Gonçalves, A.; Almeida, R.; Dias, P.; Araújo, V.; Gavina, C. \& Maciel, MJ. Transient left ventricular ballooning syndrome. European Journal of Internal Medicine. Vol.20, No.5, (2009), pp.454-456.

Stajer, D.; Mozina, H.; Noc, M. \& Rode, P. Correlation between QTcinterval durationandleft ventricular systolic dysfunction in patients with acute myocardial infarction. Journal of Electrocardiology, vol.26, No.4, (1993), 333-340.

Strunk, B.; Shaw, RE.; Bull, S.; Adams, J.; Baer, M.; Gershengorn, K.; Kao, A.; Keeffe, B.; Sklar, J.; Sperling, D.; Sperling, R.; Wexman, M. \& Young, J. High incidence of focal left ventricular wall motion abnormalities and normal coronary arteries in patients with myocardial infarctions presenting to a community hospital. Journal of Invasive Cardiolology, Vol.18, No.8, (2006), pp.376-381.

Suzuki, K.; Osada, N.; Akasi, YJ.; Suzuki, N.; Sakakibara, M.; Miyake, F.; Maki, F. \& Takahashi, Y. An atypical case of "Takotsubo cardiomyopathy" during alcohol withdrawal: abnormality in the transient left ventricular wall motion and a remarkable elevation in the ST segment. Internal Medicine. Vol.43, No.4, (2004), pp.300-305.

Takayama, N.; Iwase, Y.; Ohtsu, S. \& Sakio, H. “Takotsubo" cardiomyopathy developed in the postoperative period in a patient with amyotrophic lateral sclerosis. Masui, Vol.53, No.4, (2004), pp.403-406.

Takigawa, T.; Tokioka, H.; Chikai, T.; Fukuschima, T.; Ishizu, T. \& Kosogabe, Y. A case of undiagnosed "takotsubo" cardiomyopathy during anesthesia. Masui, Vol.52, No.10, pp.1104-1106.

Tamura, A.; Kawano, Y.; Watanabe, T.; Aso, T.; Abe, Y.; Yano, S. \& Kadota, JA. Report of 2 cases of transient mid-ventricular ballooning. International Journal of Cardiology, Vol.122, No.2, pp.10-12.

Teh, AW.; New, G. \& Cooke, J. A Single-centre Report on the Characteristics of Tako-tsubo Syndrome. Heart, Lung and Circulation, Vol.19, No.2, (2010), pp.63-70.

Trebouet, E.; Lipp, D.; Dimet, J.; Orion, L. \& Fradin, P. Cardiologic emergencies and natural disaster. Prospective study with Xynthia tempest. Annales de Cardiologie et d' Angeiologie. Vol.60, No1, (2011), pp.39-41.

Tsuchihashi, K.; Ueshima, K.; Uchida, T.; Oh-mura, N.; Kimura, K.; Owa, M.; Yoshiyama, M.; Miyazaki, S.; Haze, K.; Ogawa, H.; Honda, T.; Hase, M.; Kai, R. \& Morii, I. Transient left ventricular apical ballooning without coronary artery stenosis: a novel heart syndrome mimicking acute myocardial infarction. Angina PectorisMyocardial Infarction Investigations in Japan. Journal of the American College of Cardiology, Vol.38, No.1, (2001), pp.11-18. 
Ueyama, T.; Hano, T.; Kasamatsu, K.; Yamamoto, K.; Tsuruo, Y. \& Nishio, I. Estrogen attenuates the emotional stress-induced cardiac response in the animal model of Tako-tsubo (Ampulla) cardiomyopathy. The Journal of Cardiovascular Pharmacology, Vol.42, No.S1, (2003), pp.117-119.

Valbusa, A.; Abbadessa, F.; Giachero, C.; Vischi, M.; Zingarelli, A.; Olivieri, R. \& Visconti, LO. Long-term follow-up of Tako-Tsubo-like syndrome: a retrospective study of 22 cases. The Journal of Cardiovascular Medicine, Vol.9, No.8, (2008), pp.805-809.

Van de Walle, SO.; Gevaert, SA.; Gheeraert, PJ.; De Pauw, M. \& Gillebert, TC. Transient stress-induced cardiomyopathy with an "inverted takotsubo" contractile pattern. Mayo Clinic Proceedings Mayo Clinic, Vol.81, No.11, (2006), pp.1499-1502.

Vidi, V.; Rajesh, V.; Singh, PP.; Mukherjee, JT.; Lago, RM.; Venesy, DM.; Waxman, S.; Pyne, CT.; Piemonte, TC.; Gossman DE. \& Nesto, RW. Clinical characteristics of takotsubo cardiomyopathy. The American Journal of Cardiology, Vol.104, No.4, (2009), pp.578 -582.

Villareal, RP.; Achari, A.; Wilansky, S. \& Wilson, JM. Anteroapical stunning and left ventricular outflow tract obstruction. Mayo Clinic Proceedings Mayo Clinic, Vol.76, No.1, (2001), pp.76:79.

Watanabe, H.; Kodama, M.; Okura, Y.; Aizawa, Y.; Tanabe, N.; Chinushi, M.; Nakamura, Y.; Nagai, T.; Sato, M. \& Okabe, M. Impact of earthquakes on takotsubo cardiomyopathy. Journal of American Medicine Association, Vol.294, No.3, (2005), pp.305-307.

Winogradow, J.; Geppert, G.; Reinhard, W.; Resch, M.; Radke, PW. \& Hengstenberg, C. Tako-tsubo cardiomyopathy after administration of intravenous epinephrine during an anaphylactic reaction. International Journal of Cardiology. Vol.147, No.2, (2011), pp.309-311.

Wittstein, IS.; Thiemann, DR.; Lima, JA.; Baughman, KL.; Schulman, SP.; Gerstenblith, G.; $\mathrm{Wu}, \mathrm{KC}$.; Rade, JJ.; Bivalacqua, TJ. \& Champion, HC. Neurohumoral features of myocardial stunning due to sudden emotional stress. The New England Journal of Medicine,Vol.352, No.6, (2005), pp.539-548.

Yanagi, S.; Nagae, K.; Yoshida, K.; Matsumura, Y.; Nagashima, E.; Okada, M.; Ota, T.; Hirota, K. \& Yoshikawa, J. Evaluation of coronary flow reverse using Doppler guide wire in patients with ampulla cardiomyopathy: three case reports. Journal of Cardiology, Vol.39, No.6, (2002), pp.305-312.

Yasu, T.; Tone, K.; Kubo, N. \& Saito, M. Transient mid-ventricular ballooning cardiomyopathy: a new entity of Takotsubo cardiomyopathy. International Journal Cardiology, Vol.110, No.1, (2006), pp.100-101.

Yoshida, T.; Hibino, T.; Kako, N.; Murai, S.; Oguri, M.; Kato, K.; Yajima, K.; Ohte, N.; Yokoi, K. \& Kimura, G. A pathophysiologic study of tako-tsubo cardiomyopathy with F-18 fluorodeoxyglucose positron emission tomography. European Heart Journal, Vol.28, No.21, (2007), pp.2598-2604.

Yunus, A.; Gillis, AM.; Duff, HJ.; Wyse, DG. \& Mitchell, LB. Increased precordial QTc dispersion predicts ventricular fibrillation during acute myocardial infarction. The American Journal of Cardiology, Vol.78, No.6, (1996), pp.706-708. 
Zaroff, JG.; Rordorf, GA.; Ogilvy, CS. \& Picard, MH. Regional patterns of left ventricular systolic dysfunction aftersubarachnoid hemorrhage: evidence for neurally mediated cardiac injury. The Journal of the American Society of Echocardiography, Vol.13, No.8, (2000), pp.774-779.

Zdanowicz, JA.; Utz, AC.; Bernasconi, I.; Geier, S.; Corti, R. \& Beinder, E. "Broken heart" after cesarean delivery. Case report and review of literature. Archives of Gynecology and Obstetrics, Vol.283, No.4, (2011), pp.687-694. 


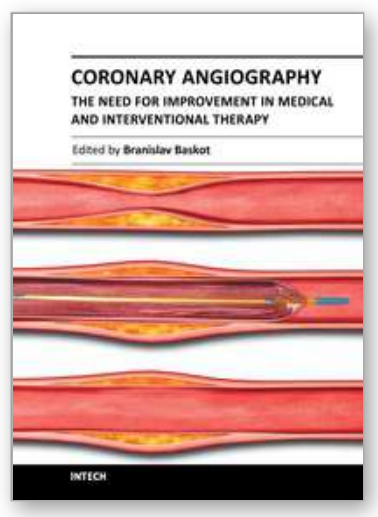

\section{Coronary Angiography - The Need for Improvement in Medical and Interventional Therapy}

Edited by Prof. Baskot Branislav

ISBN 978-953-307-641-6

Hard cover, 206 pages

Publisher InTech

Published online 06, September, 2011

Published in print edition September, 2011

In this book we examined a periprocedural complication of coronary angiography, and coronary intervention. That includes related to cardiac catheterization and diagnostic coronary angiography, and those that occur as a consequence of the specific equipment. However, improvements in devices, the use of stents, and aggressive antiplatelet therapy have significantly reduced the incident of major periprocedural complications. This book giving knowledge and experiences many of interventional cardiologists from all over the world, and provide possibility to recognize new approach in this domain. Book gives lecture on how we image and how we decide on what to treat, how to treat it, and then results of that treatment. They offer many answers to what we have today and what we will have tomorrow.

\section{How to reference}

In order to correctly reference this scholarly work, feel free to copy and paste the following:

Montassier Emmanuel, Segard Julien, Arnaud Martinage, Nicolas Piriou, Philippe Le Conte, Gilles Potel and Jean Pierre Gueffet (2011). Tako-Tsubo Cardiomyopathy: A Recent Clinical Syndrome Mimicking an Acute Coronary Syndrome, Coronary Angiography - The Need for Improvement in Medical and Interventional Therapy, Prof. Baskot Branislav (Ed.), ISBN: 978-953-307-641-6, InTech, Available from: http://www.intechopen.com/books/coronary-angiography-the-need-for-improvement-in-medical-andinterventional-therapy/tako-tsubo-cardiomyopathy-a-recent-clinical-syndrome-mimicking-an-acute-coronarysyndrome1

\section{INTECH}

open science | open minds

\section{InTech Europe}

University Campus STeP Ri

Slavka Krautzeka 83/A

51000 Rijeka, Croatia

Phone: +385 (51) 770447

Fax: +385 (51) 686166

www.intechopen.com

\section{InTech China}

Unit 405, Office Block, Hotel Equatorial Shanghai

No.65, Yan An Road (West), Shanghai, 200040, China

中国上海市延安西路65号上海国际贵都大饭店办公楼 405 单元

Phone: +86-21-62489820

Fax: $+86-21-62489821$ 
(C) 2011 The Author(s). Licensee IntechOpen. This chapter is distributed under the terms of the Creative Commons Attribution-NonCommercialShareAlike-3.0 License, which permits use, distribution and reproduction for non-commercial purposes, provided the original is properly cited and derivative works building on this content are distributed under the same license. 